\title{
Was There a Santa María Culture? \\ A Discussion of a Commonly Used Concept in Argentine Archaeology
}

\author{
Per Cornell \& Nils Johansson
}

\begin{abstract}
In this article the Santa Maria culture, a commonly used concept in Argentine archaeology, is discussed. Historically, this concept has been given varying definitions, which all have to be evaluated. As far as we understand, only aspects of the variability in artifacts, etc., have been used to define cultural units. A more fruitful and perhaps more empirical approach estimates the general variability without a priori assuming one single explanation or interpretation for this variability.
\end{abstract}

Per Cornell, Department of Archaeology, Göteborg University, Box 200, SE-405 30 Göteborg, Sweden.

Nils Johansson, Central Board of National Antiquities, SE-43423 Kungsbacka, Sweden.

\section{INTRODUCTION}

Through 1989-94 excavations were undertaken at the site of El Pichao in north-western Argentina. They were undertaken as a joint venture between Swedish and Argentine archaeologists. As a result, a general chronology of the site was developed, covering the time period AD 1000-1700 (Cornell \& Johansson 1993). Intensive work on one single site was quite fruitful. However, this specific site must be put into a regional context. As a continuation of the project, we now intend to study settlement variability over a larger area. In order to do so, some cultural concepts commonly used in NW Argentine archaeology must be evaluated.

\section{BACKGROUND}

The Santa María culture is a common concept in north-west Argentine archaeology. This culture is often represented by a funeral vessel for children, named the Santa María urn. Historically, this culture has been given many different extensions and many different names. During the first part of our century archaeologists often called it the Calchaqui or the Diaguita culture.

Major contributions to this discussion were made at the end of the 19th century and the beginning of the 20th by scholars like Juan B Ambrosetti, Eric Boman, Carlos Bruch, Samuel A Lafone Quevedo, Erland Nordenskiöld, Adán Quiroga, Eric von Rosen, ten Kate and Max Uhle. Only a few of them organised more systematic excavations, and their efforts remained often quite "impressionistic". Still, they created a sort of data base, or points of reference, which was an important pioneer work. This generation of

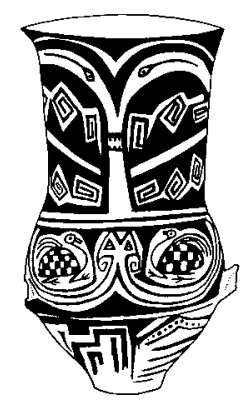

Fig. 1. A Santa Maria urn, the type artifact representing the Santa María culture. Drawing by Anders Andersson. 


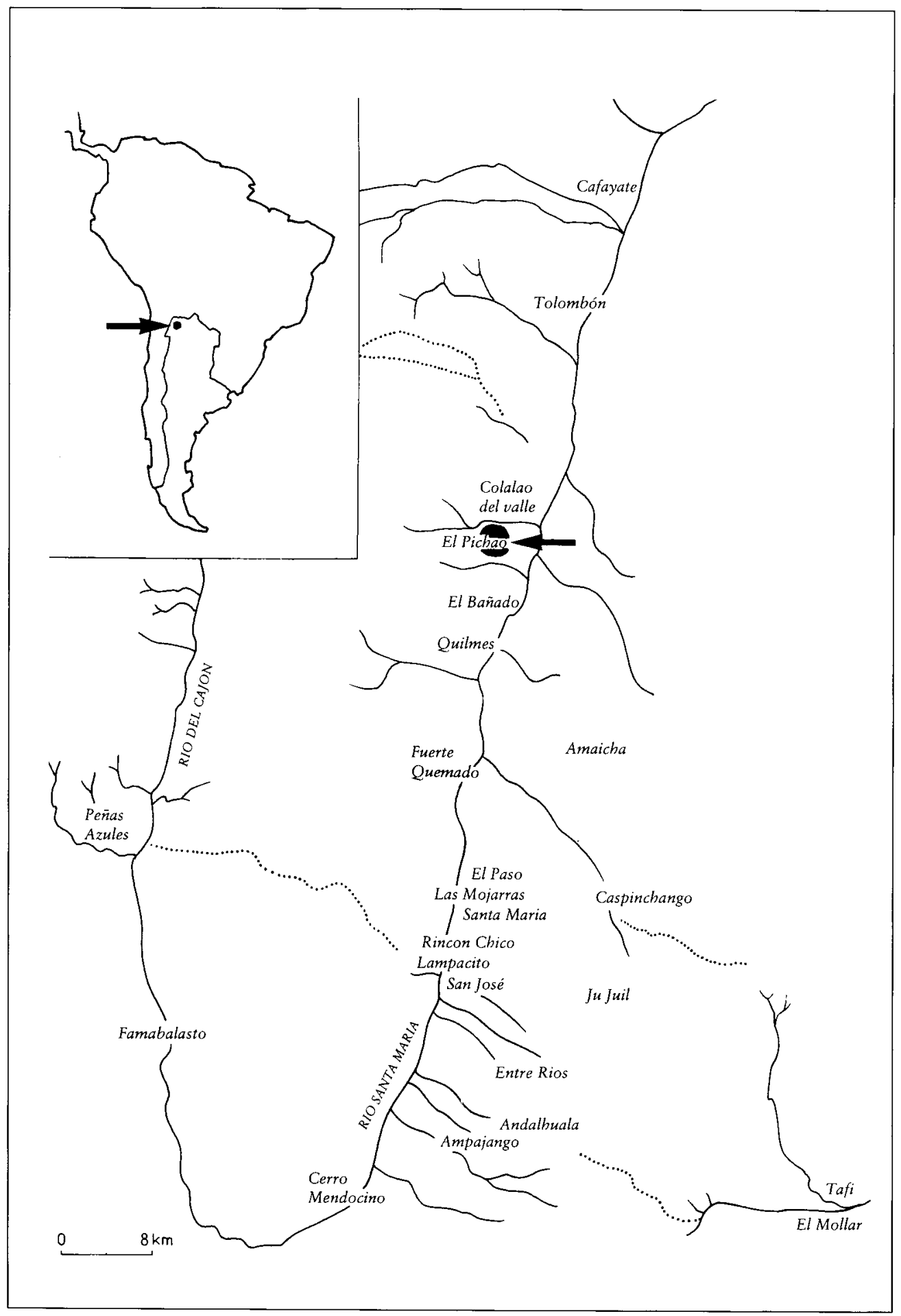

Fig. 2. Sites in the Santa Maria valley, one of the valleys where the Santa Maria urn is encountered. Drawing by Anders Andersson. 


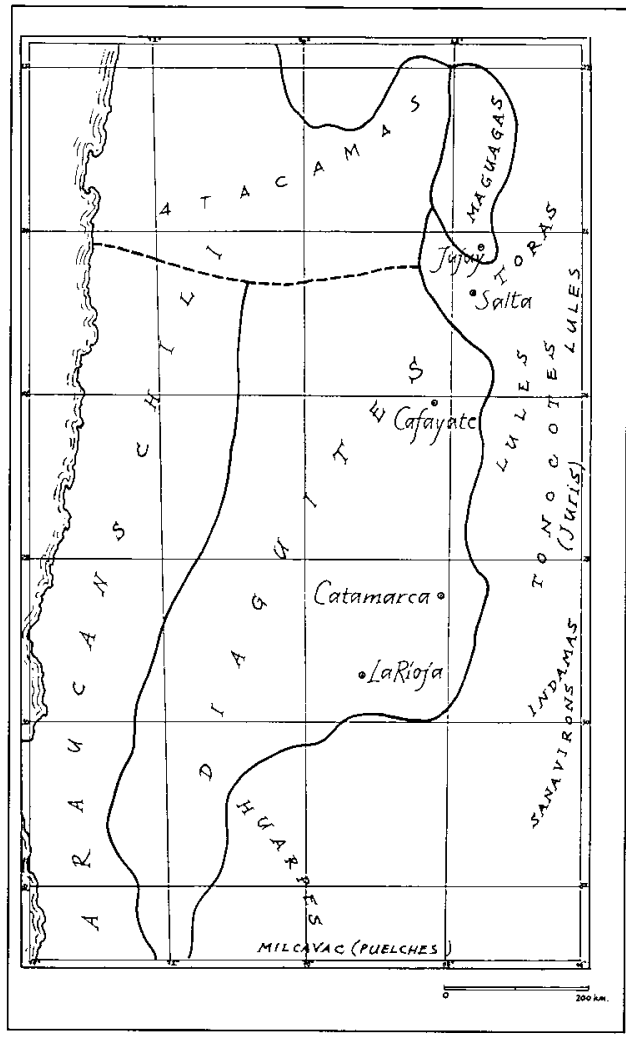

Fig. 3. The extension of the Diaguita culture according to Boman (Redrawn from Boman 1908 by Anders Andersson).

scholars also created an interpretative framework which to some extent is still applied in the archaeology of the area (cf. Núñez Regueiro 1974; Arenas 1991-92; Cornell 1996, for general discussion).

\section{DEFINING THE CULTURAL UNIT: DIFFERENT PERSPECTIVES}

According to Juan B Ambrosetti, an Argentine archaeologist, the Calchaqui people were a unique cultural unit, a people of a special race. $\mathrm{He}$ associated it with ceramic vessels found particularly in the Santa María Valley, but gave it a wide distribution. The extension was never defined in detail, but it was said to have included the area from the Bolivian highland in the north down to the San Juan and even the Cordoba province of Argentina (Ambrosetti 1903). These vessels were often richly deco- rated with repetitive patterns, and they often contained the skeletal remains of babies or young children. In some works Ambrosetti linked the Calchaqui people to the Pueblo societies in southern USA, and discussed them in terms of the only remains of an otherwise extinct race.

Eric Boman, originally from the province of Dalarna, Sweden, but later a naturalised Argentinian, criticized Ambrosetti. Though Boman accepted the general idea of the prehistoric existence of a Diaguita people, he considered them part of a general Andean phenomenon, part of what he called the AndoPeruvian race. In his large study on the antiquities from NW Argentina, published in French in 1908, he constructed an "ethnic map" of the prehistory of the area. The Diaguitas inhabited a large area extending from Navados de Acay and the Valle de Lerma, to the far south, and to the province of Mendoza. Other units, marked on the map and defined as "Peoples" (without any more detailed discussion), include the Tonocotés of the plains east of the mountains, the Araucans of present-day Chile, the Atacamas of the highland puna in the area of the desert of Atacama, the Uros (or Changos) in the area further north, and others. Within each of these there were, according to Boman, different "tribes". Within the Diaguitas there were, for example, Tolombons, Taris, etc. Boman also defined the relative position of these peoples on a scale of civilization. The Diaguitas were the most civilized, while the Tonocotés, the Araucans, and the Uros were more or less savages. The Atacamas were not savages, but neither were they as civilized as the Diaguitas.

Boman's "ethnic map" was largely based on two written sources: a description written by Pedro Sotelo Narvaez in 1583, and a letter to the Jesuit base from P Alonso de Barzana, written in 1594. These sources are not simple and straightforward to interpret, and the use of terms is not defined or explained. Careful reading of detailed administrative reports concerning other areas indicate that the meaning of general terms used in the colonial discourse is very complex. 


\section{THE PEOPLE OF THE DIAGUITA}

In order to substantiate the argument, Boman used archaeological material. Comparing the Atacamas and the Diaguitas, Boman tried to define these groups. The Diaguitas had developed advanced ceramic technology, stone sculpture technology, and metallurgy, but all these skills were lacking, according to Boman, among the Atacamas. The Atacamas only mastered a highly developed tradition in working textiles and bones (Boman 1908:767-778). The archaeological remains of the Humahuaca Valley were defined as Calchaqui by Ambrosetti (i.e. linking them to cultures further south), while Boman defined them as Atacamas. Comparing the Diaguitas and the "Peruvian culture", Boman stressed similarities (1908: 187-212): both built houses of stone; used terracing for cultivation; made ceramics, stone sculptures, and mattocks of similar types and used similar techniques in metallurgy. Boman believed that burying children in urns was not common in Peru, and thus was a specific trait of the Diaguitas.

Boman also notes that some artifact types vary within his "People" units. He mentions the lithic technology, which varies within the area defined as belonging to the Atacamas (Boman 1908:571, 773). In some areas he even reports the absence of lithic technology (1908:357).

In an extensive footnote added to the text, Boman discussed the findings of Ambrosetti at the La Paya site high up in the Calchaqui river valley. Boman concludes that these remains must be ascribed to the Atacamas group. There are some burial urns for children with a decoration similar to that found in the Santa María Valley at La Paya, but Boman explains them as imported items (note, Boman 1908:778). These observations thus changed the northern border of the Diaguita phenomenon in relation to Bomans ethnic map.

Boman generally does not discuss chronological questions. In relation to some findings in Jujuy, excavated by Boman and the wellknown Swedish ethnographer Erland Nordenskiöld, he discussed a series of successive cultural migrations. Large funerary vessels, containing adults (probably primary burial), are interpreted as remains from a Guarani expansion into this area, while vessels with some decoration and the remains of small children are interpreted as vestiges of a Diaguita expansion into this area (Boman 1905, 1908:852).

Nordenskiöld discussed the material from Jujuy in similar terms. He actually returned to this material in various studies. In a preliminary report from 1903, he discussed the cultural identity of the material but could not arrive at any more definite conclusion. He tended to believe that the material was more linked to the cultures of the Chaco area than to the "Calchaqui people". In later, more general studies he discussed the "positive" influence of the "mountain culture" on the people living east of the mountains (Nordenskiöld 1919: 235-251, 1920:203). In one of his last publications, Nordenskiöld once again discussed the relation between the Diaguita and the cultures east of the Andes. He defines the Diaguita as a largely Andean culture, but with a strong "Amazonian" influence in ceramics, particularly on the type of funerary vessel often found in the Santa María Valley (1930:32, cf. Rydén 1956 for a discussion).

\section{CHRONOLOGY AND CULTURAL UNITS}

Max Uhle was a German archaeologist living and working for several years in different South American countries. He did not excavate, but he collected items in Argentina, generally through purchase, in the beginning of the 1890s (Uhle 1904). In 1912 he published a path-breaking study on the chronology of NW Argentina. Uhle tried to transfer an earlier developed Peruvian chronology to Argentina. He based his chronology on studies of pottery, and made a division into three different periods.

1. The period of decorated vases with dragon motifs (the Aguada style in modern terminology)

2. A pre-Incaic period with early Santa María ceramics. 
3. The period of Incaic influence with late Santa María ceramics.

Uhle considered that the prehistoric cultures of the Santa María valley were neither totally indigenous nor introduced by the Incas. Some things such as metallurgy and the Quechua language were, however, introduced by the Incas. Uhle's scheme is generally accepted today.

Immediately after its publication in 1912 , Uhle's chronological scheme was, however, questioned by archaeologists such as Eric Boman and Juan B Ambrosetti, who both considered that the observed differences in urn styles were of a synchronic rather than a diachronic character. According to Boman, the "draconian" ceramics and the Santa María urn were contemporaneous. Carbon-14 datings support Uhle's argument, but some of Boman's critical points constitute, even today, a serious challenge. Boman pointed to the lack of correspondence between the distribution of the "draconian" ceramics and that of the Santa María ceramics. Only further fieldwork in the Santa María Valley and adjacent areas may shed light on this problem.

\section{THE SANTA MARÍA CULTURE}

Up to the end of the 1940s the Diaguita was generally understood as a homogeneous culture, a "People". A study by Fernando Marquez Miranda from 1946 constitutes, perhaps, the most extreme example of this position. A study by some US-American archaeologists, working on collections, initiated a trend of greater sensitivity to chronology (Bennett, Bleiler \& Sommer 1948). The outline of modern NW Argentine chronology was, however, developed by Alberto Rex Gonzalez in the early 1960s. He and his pupils carried out major work on chronology. Gonzalez was trained by, and received influence from, scholars of different traditions: Oswald Menghin, Julian Steward, James Ford and others. Thus, Gonzalez knew a lot about the Kulturkreislehre favoured by Menghin, but was also aware of Steward's discussion on the "culture core". From this surged a very special type of archaeology. Gonzalez used the term "cultural context". He defined this as a series of traits (artifacts and other material remains) occurring together in a specific area, defining a particular culture. This definition is congruent with Kulturkreislehre, but also with Gordon Childe's famous definition of (archaeological) culture as a set of artifacts occurring together repetitively.

Gonzalez developed his major studies on archaeological remains in the Hualfín Valley, where he developed a master sequence (partially working on collections) still applied in NW Argentina (Gonzalez 1975). He combined pottery encountered in cultural layers, grave associations and ${ }^{14} \mathrm{C}$ datings to produce a chronological framework. In this scheme, the Santa María culture and its type artifact, the Santa María urn, are placed within the "Late Period", AD 850-1480. Discussing the Santa María Valley, he defined a Santa María Culture (Gonzalez 1980:319-341). This culture extended over the Cajón valley and the Santa María Valley and up the Calchaqui Valley, into the south of Salta and to the province of Tucumán in the east. It is mainly defined by large funerary vessels with decoration in two or three colours, often used for burying children. Gonzalez also mentions stone-walled houses, agricultural terraces, and elaborate ceramic styles, including the funerary vessels of different types (called e.g. La Paya, Pampa Grande, El Rincón and Las Mojarras) and other types of ceramics, notably the Yocavil type and the Famabalasto type. The Santa María Culture also had an elaborate metallurgical tradition. They kept camelids, hunted ñandu and other animals, and cultivated maize and beans. Around the Santa María culture there were other cultures of similar types but with slight differences in material culture, for example the Belen culture.

\section{DISCUSSION}

In the discussion of cultural units in the region in question, we can see how there are several, not totally overlapping, concepts in operation. 
For example, the Diaguita and the Calchaqui people are similar, but not identical concepts. The La Paya material is crucial here. While this material was included in the Calchaqui people category (and later in the Santa Maria Culture concept), it was excluded in the Diaguita category. When these concepts are used: and they still occur frequently in the literature: the definition in terms of archaeological remains is vague and very general. The concept of the Santa María Culture was linked more systematically to archaeological evidence by Gonzalez, and the distribution in space was much more limited. The discussion by Gonzalez demonstrates his deep knowledge of the archaeology of the region, and his systematic approach to the craft. However, the definition of the cultural context is not entirely satisfactory. Still, we do not know why he gives particular importance to certain elements, and less importance to others.

In some recent literature, the culture concept has been replaced by a definition based on political forms. Ana Maria Lorandi considers that the Santa María culture represents a specific level of socio-political development. In her opinion, NW Argentine cultures during the period in question were organised as large chiefdoms (Lorandi \& Ottonello 1985). These were later destroyed during the Incaic conquest. The socio-political definition has never been discussed systematically in relation to the archaeological evidence. In most discussions of chiefdoms and early states, the definition is based on site hierarchies. Sites are ordered according to size, and if there is a pattern with a few very large sites, some intermediate size sites and several smaller sites, this is seen as indicating the existence of an administrative system. This argument is actually hard to sustain (Cornell 1993). Variation in size may be caused by several different factors. The argument is better if it is combined with direct indications of administration (e.g. particular administrative buildings). However, no such scheme has been elaborated for the Santa María Valley, and the present knowledge of the archaeological remains of the region does not support such a hypothesis. Another type of argument links the political organisation to just one large, very special, site, for example the Inca administrative site at Huanuco Pampa. There is no such unusually large and very special site in the Santa María Valley proper. Other types of argument use particular inscriptions, as in the Maya case. There is no such evidence in the Santa María Valley. Thus, at present the hypothesis of a pre-Hispanic chiefdom in the Santa María Valley is viable, but not supported by archaeological evidence. The written sources do not substantiate the argument either, as far as we know.

\section{CONCLUDING REMARKS}

There are traits that occur repetitively during particular periods in NW Argentine prehistory. But the interpretation of these features is not straightforward. There may be different explanations or interpretations for different attributes and their spatial distribution. Some aspects may be explained by mere functional explanations (e.g. the use of local lithic material), while other aspects may be interpreted by more complex social patterns. It cannot be excluded that there were different, partially overlapping, social group identities operating in the area. Tartusi \& Núñez-Regueiro proposes, for example, that the so-called Condorhuasi "culture" actually corresponds only to a specific type of ceremonial ceramics, not linked to specific "cultures" (Tartusi \& NúñezRegueiro 1993). We can thus never know to what ethnic group the individual Indian considered himself to belong. Perhaps it would be more suitable to look for variation in a more general sense, and interpret particular traits and correlated traits, rather than to look for possibilities to delimit specific cultures. Different levels of integration can be identified, in some instances overlapping such. At a basic level, the household may be a basic social unit (Cornell 1993, 1995/1996). The site may be another unit.

At the Pichao site the distribution of water, for example, required some general co-ordination at the site level. There may, however, be 
other special integrative levels within a site. Some of the pottery, for example, may have been produced by a group of specialists (Sjödin 1996). In a regional perspective, common traits include the use of a range of domesticated animals and plants, imported obsidian, some shared ceramic styles and forms, and a common grave shape (Johansson 1996). The distribution of these attributes in time and space does not correspond, and it is unlikely that they can be explained or interpreted by one general model.

Our conclusion is that it is difficult to use the concept of a Santa Maria Culture or Santa María chiefdom in general terms. There is a need for more empirical work, for systematic study and comparision of assemblages at different sites in different natural habitats displaying "Santa María ceramics". Which traits are local? What sort of similarities are there? Do the patterns of distribution of different traits overlap? Are there different levels of integration, as evidenced in the material culture? What do these levels of integration mean in social and cultural terms? Is the distribution of different patterns continuous in space?

The repeated patterns and motifs of decoration on the Santa María urns is a particular trait, which may have a specific interpretation. These patterns may have been produced by potters who specialised in the production of funerary vessels. The decoration on the Santa María ceramics may correspond to a few similar histories or myths common to a lot of people in a large area. The so-called Santa María culture was not constituted by common building traditions or general artifact similarity but by materialised myths, evident in the decoration on some ceramic material. The importance of this ceramic style has been discussed by many archaeologists. There are even (all too) fantastic structuralist interpretations on these patterns, based only on objects in museum collections (Weber 1981).

Thus, we may perhaps conclude that the reality of the Santa María Culture may turn out to be a myth.

\section{English revised by Laura Wrang.}

\section{REFERENCES}

Ambrosetti, J. B. 1903. I Calchaqui. Societá Geografica Italiana, 5, Roma.

Arenas, P. 1991-92. La antropología en la Argentina a fines del siglo XIX y principios del XX. Runa, XIX. Pp. 147-60. Buenos Aires.

Bennett, W. C., Bleiler, E. F. \& Sommer, F. H. 1948. Northvest Argentine Archaeology: Yale University Publications in Anthropology, 38, New Haven.

Boman, E. 1905. Migrations précolombiennes dans le Nord-ouest de l'Argentine. Journal de la Socièté des Americanistés de Paris, NS, Vol 2. Pp. 99-108.

- 1908. Antiquités de la region andine de la République Argentine et du désert d'Atacama, I-II. Imprimiére Nationale, Paris.

Cornell, P. 1993. Early Centres and the Household. A theoretical and methodological study on Latin American cases. GOTARC series B, Gothenburg Archaeological Theses no 3. Göteborg University.
-1995/1996. The definition of the study object and the study of production processes in archaeology. Revista de História da Arte e Arqueologia, No 2. Campinas. Pp. 19-29.

- 1996. Swedish archaeological fieldwork in the Americas and Americanistic collections and museums in Sweden. XIII International Congress of Prehistoric and Protohistoric Sciences, Forli, Italia, 8-14 September 1996, Colloquia 17: The Prehistory of the Americas. Forlí. Pp. 67-73.

Cornell, P. \& Johansson, N. 1993. Desarrollo del asentamiento del sitio S TucTav 5 (El Pichao), Provincia de Tucumán. Comentarios sobre datciones de 14C y Luminiscencia. Publicaciones, 2. Instituto de arqueología, Universidad Nacional de Tucumán. Pp. 31-43.

Gonzalez, A.R. 1980. Arte Precolombino de la Argentina. Buenos Aires.

Gonzalez, A. R. \& Cowgill, G. 1975. Cronología del Valle de Hualfín, provincia de Catamarca, 
Argentina. Actas del Primer Congreso de Arqueologia Argentina. Buenos Aires. Pp. 383395.

Johansson, N. 1996, Burials and Society - A Study of Social Differentiation at the Site of El Pichao, North-western Argentina, and in Cemeteries Dated to the Spanish Native Period. GOTARC series B. Gothenburg Archaeological Theses, no 5. Göteborg University.

Lorandi, A. M. \& Ottonello, M. M. 1985. Introducción a la arqueología y la etnología. Buenos Aires.

Márquez-Miranda, F. 1946. Los Diaguitas. Inventario patrimonial arqueológico y paleoetnográfico. Revista del Museo de La Plata (N.S.). Univ. Nac. de La Plata, Sección antropología, III. Pp. 1-295.

Nordenskiöld, E. 1903. Präcolombische Wohnund Begräbnisplätze an der Süd-Westgrentze von Chaco. Kungliga Svenska Vetenskapsakademiens handlingar, vol. 36, 7 .

- 1919. An ethno-geographical analysis of the material culture of two Indian tribes in the Gran Chaco. Comparative Etnological studies, 1. Göteborg.

- 1920. The changes in the material culture of two Indian tribes under the influence of new surroundings. Comparative Etnological studies, 2. Göteborg.

- 1930. L'archéologie du bassin de l'Amazone, Paris.
Núñez-Regueiro, V. 1974. Conceptos instrumentales y marco teórico en relación al análisis del desarollo cultural del Norooeste Argentino. Revista del Instituto de Antropología, V. Cordoba. Pp. 169-190.

Rydén, S. 1956. The Erland Nordenskiöld archaeological collection from the Mizque Valley, Bolivia. Etnologiska studier, 26. Göteborg.

Sjödin, S. 1996. Appendix $4-$ An analysis of ceramic fragments from the Amancay cemetery. In: Johansson, N. 1996. Burials and Society-A study of Social Differentiation at the Site of El Pichao, North-western Argentina, and in Cemeteries dated to the Spanish Native period. GOTARC series B. Gothenburg Archaeological Theses, no 5. Göteborg University.

Tartusi, M. \& Núñez-Regueiro, V. 1993. Centros ceremoniales del NOA, Publicaciones 5 . Instituto de arqueología, Universidad Nacional de Tucumán. Pp. 1-49.

Uhle, M. 1904. Bericht über die Ergebnisse meiner Südamerikanischen reisen. Internationaler Amerikanisten-Kongress, Stuttgart. Pp. 567579.

- 1912. Las relaciones préhistoricas entre el Peru y la Argentina. XVII Congreso Internacional de Americanistas. Buenos Aires. Pp. 509-540.

Weber, R. L. 1981. An analysis of Santa María urn painting and its cultural implications. Fieldiana anthropology ns 2. 